\title{
Modelling Stream Flow of Altuma Catchment using SWAT
}

\author{
J. Padhiary', D.M. Das ${ }^{2 *}$, A.P. Sahu ${ }^{2}$ and B.C. Sahoo ${ }^{2}$ \\ ${ }^{1}$ Deapartment of Civil Engineering, NIT Rourkela, India \\ ${ }^{2}$ SWCE, CAET, OUAT, India \\ *Corresponding author
}

A B S T R A C T

Keywords

SWAT, SUFI-2,

Streamflow, NSE,

Calibration,

Validation

Article Info

Accepted:

20 April 2018

Available Online:

10 May 2018
Surface runoff estimation from a watershed is a prerequisite for surface water assessment. Hydrological models are the only tool to assess the flow from a watershed under different scenarios. The Soil and Water Assessment Tool (SWAT), a physically based hydrological model, is used modelling monthly streamflow in Altuma catchment. The model was calibrated from 1985 to 1996 . Initial 3 years from 1985 to 1987 were taken as warm up periods. Then the model was validated for 7 years from 1997 to 2003 . Two indices, pfactor and r-factor were considered for analyzing uncertainty of the model. The simulation results of the model showed that p-factor and r-factor were 0.80 and 0.75 respectively, during calibration and while, during validation $\mathrm{p}$-factor and r-factor were 0.69 and 0.70 respectively. The performance of the model was evaluated by coefficient of determination $\left(\mathrm{R}^{2}\right)$ and the Nash-Sutcliffe efficiency (NSE). The $\mathrm{R}^{2}$ and NSE were found 0.78 and 0.74 for the calibration period and 0.69 and 0.67 for the validation period. The result has shown that the model performance was satisfactory during calibration and validation. The results would be helpful for water resources planning and management in the catchment area.

\section{Introduction}

The per-capita water availability is limiting day by day due to population growth, rapid industrialization and urbanization in all the countries. Hence, it is very important to judicially use the available water for present future requirement. Hydrologic modelling is very essential tool for water resources management. The impact of soil, topography, land use and climate change on streamflow can be successfully assessed by a well distributed hydrological model (Patel and Srivastava 2013). Semi-distributed hydrologic models, such as the Soil and Water
Assessment Tool (SWAT) (Arnold et al., 1998) have been widely used for hydrologic processes simulation for water management. In the present situation, SWAT has been used for streamflow estimation in basin scale (Zhang et al., 2010; Yesuf et al., 2016). Goyal et al., (2014) used the soil and water assessment tool (SWAT) to simulate the hydrologic characteristics of the watershed in Jamaica to assess streamflow availability for irrigation supply during dry periods and its feasibility for agricultural water scarcity planning. The model is also used for estimation of both streamflow and sediment yield in the catchment (Mishra et al., 2007; 
Pinto et al., 2013). The impact of climate change on streamflow has been analyzed in basin scale using this model (Dahal et al., 2016). Sun et al., (2013) used SWAT to simulate the streamflow and studied the effect of climate change on streamflow in the Kadongjia watershed located in southern Tibet, China, and found that streamflow was more sensitive to climate change in winter and spring than in the other two seasons. In this study the objectives were to set up the SWAT model to simulate the monthly streamflow and to evaluate the uncertainty in streamflow estimation using SUFI-2 algorithm in Altuma Catchment of Brahmani river basin.

\section{Description of the study area}

The Brahmani river basin lies between $83^{\circ} 52^{\prime}$ to $87^{\circ} 03^{\prime}$ east longitudes and $20^{\circ} 28^{\prime}$ to $23^{\circ} 35^{\prime}$ north latitudes (Fig. 1). The basin has maximum elevation of about $600 \mathrm{~m}$ and covers 39,033 Sq.km area. From the basin Altuma catchment was selected for this study. The total area of the catchment is 1332 Sq.km. The temperature varies from $30-36^{\circ} \mathrm{C}$ during summer and $16-17^{\circ} \mathrm{C}$ during winter season. Rice, groundnut, sugarcane, millets and vegetables are the important crops cultivated in the area. During South-West monsoon season, the relative humidity varies from 75$90 \%$ and in the summer it varies from $30 \%$ 40\%. The average rainfall in the basin 1395 $\mathrm{mm}$.

\section{Materials and Methods}

\section{Input datasets}

Digital elevation model (DEM), land use/land cover (LULC), soil, weather and discharge data have been collected from different sources/agencies and some are also prepared for setting up the model. The details of all the datasets used in this study are listed in Table 1 .

\section{SWAT model structure}

SWAT is a semi-distributed conceptual hydrological model (Arnold et al., 1998), which can operate on both daily and monthly time-step, or even annually for long term simulation. SWAT divides the basin into number of sub basins which are joined by a stream network and further divides each sub basins into hydrologic response units (HRUs), with homogeneous land cover, slope, and soil type. The model works on principle of water balance Eq. (1):

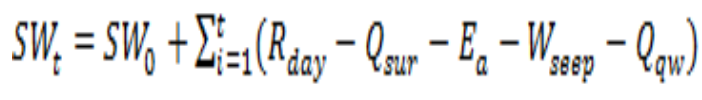

$\mathrm{SW}_{\mathrm{t}}=$ Final soil water content $(\mathrm{mm}), \mathrm{SW}_{0}=$ Initial soil water content on day $i(\mathrm{~mm}), \mathrm{R}_{\mathrm{day}}=$ Amount of precipitation on day $i(\mathrm{~mm}), \mathrm{Q}_{\text {surf }}=$ Amount of surface runoff on day $i(\mathrm{~mm}), \mathrm{E}_{\mathrm{a}}=$ Amount of evapotranspiration on day $i(\mathrm{~mm})$, $\mathrm{Q}_{\mathrm{gw}}=$ Amount of return flow on day $i(\mathrm{~mm})$. $\mathrm{W}_{\text {seep }}=$ Amount of water entering the vadose zone from the soil profile on day $i(\mathrm{~mm})$.

\section{SUFI- 2 algorithm}

The uncertainty in calibration parameters were evaluated using SUFI-2 algorithm. The uncertainty occurs in different stages of hydrological modelling such as uncertainty in model structure, model conceptualization, parameters, and measured data (Abbaspour, 2015). The uncertainty in SWAT stream flow simulation is expressed based on ninety-five percent prediction uncertainty (95PPU). The upper limit of 95PPU band is $97.5 \%$ and the lower limit of the band is $2.5 \%$ (Abbaspour et $a l ., 2007)$. The uncertainty is determined by the r-factor and p-factor (Abbaspour et al., 2015). The P-factor is defined as percentage of observation covered by the 95PPU and the $\mathrm{r}$ factor is average thickness of the 95PPU band divided by the standard deviation of the measured data. The P-factor varies from 0 to 1 
and R-factor varies from 0 to $\infty$. When the Pfactor is 1 and $\mathrm{R}$-factor is 0 , the simulated value perfectly matched with observed value (Abbaspour et al., 2007).

\section{Performance indices}

The P-factor, R-factor, $\mathrm{R}^{2}$ (Coefficient of Determination) and NSE (Nash-Sutcliff Efficiency) are four parameters used to evaluate the performance of the model. The NSE value varies from $-\infty$ to 1 (Nash and Sutcliffe, 1970) with a high value indicating an accurate model. Similarly, the range of $\mathrm{R}^{2}$ is from 0 to 1 , with a higher value meaning better performance. NSE is calculated using the following define by equations Eq. 2:

NSE $=1-\frac{\sum_{i=1}^{N}\left(O_{i}-S_{i}\right)^{2}}{\sum_{i=1}^{N}\left(O_{i}-\sigma\right)^{2}}$

Where, $O_{i}$ is observed discharges, and $S_{i}$ is simulated discharge, ${ }^{\bar{O}}$ is mean discharge and $N$ is the total number of observations.

\section{Results and Discussion}

\section{Sensitivity analysis (SA)}

Sensitivity analysis is the process of determining the rate of change in model output with respect to changes in model inputs (parameters). It is necessary to identify key parameters and the parameter precision required for calibration. Global Sensitivity analysis is conducted for nine parameters (Table 2) at the monthly time-step to determine SWAT model parameters that are very sensitive to streamflow prediction. The most sensitive parameter identified in this study wereCN2 followed by ALPHA_BF, GW_DELAY, and GWQMN.

\section{Calibration and validation}

Quantification of available water resources at catchment scale is necessary for sensible management and allocation of water in a catchment. SWAT-CUP (SWAT-Calibration and Uncertainty Programs) was used for model calibration, validation, sensitivity and uncertainty analysis, using the Sequential Uncertainty Fitting (SUFI-2) technique. The model was calibrated for period (1985 to 1996) including 3 years as warm up (1985 to 1987), subsequently model was validated for 7 years from 1997 to 2003. In calibration the pfactor and the r-factor are obtained as 0.80 and 0.75 and during validation the $\mathrm{p}$-factor and the r-factor are obtained as 0.69 and 0.70 respectively. The uncertainties in the model during calibration and validation are within permissible limits because most of the observed values are within the 95PPU band (Fig. 2 and 3).

Fig.1 Location of study area

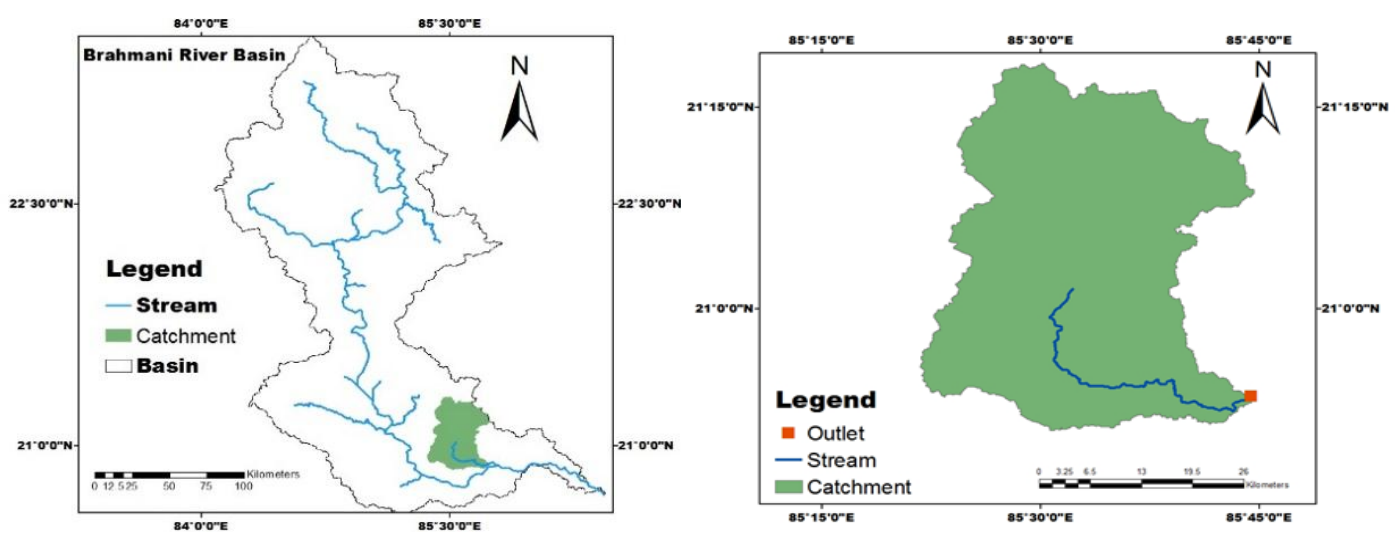


Fig.2 Plot of observed and simulated streamflow with 95ppu during calibration

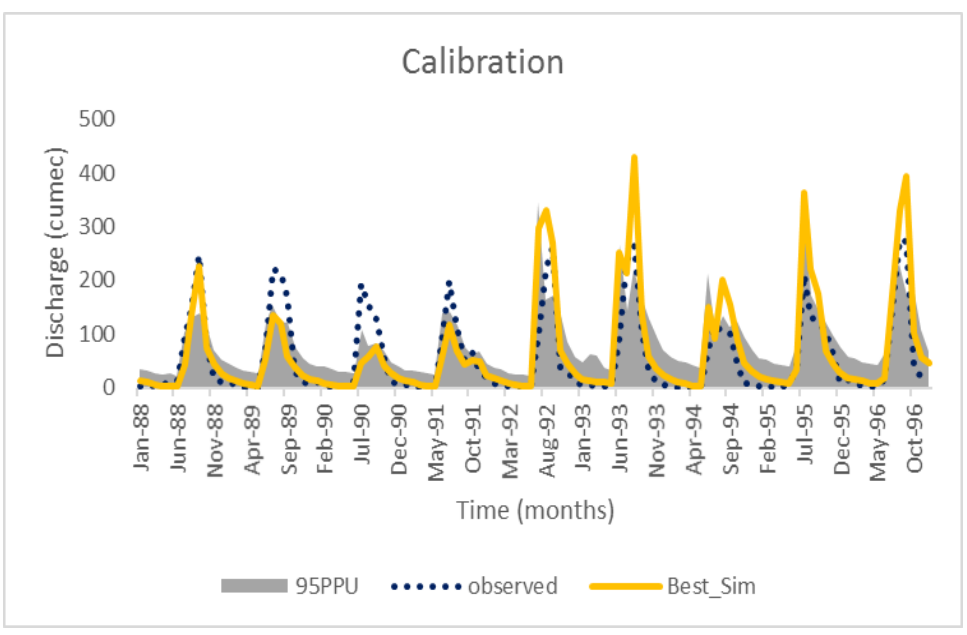

Fig.3 Plot of observed and simulated streamflow with 95ppu during validation

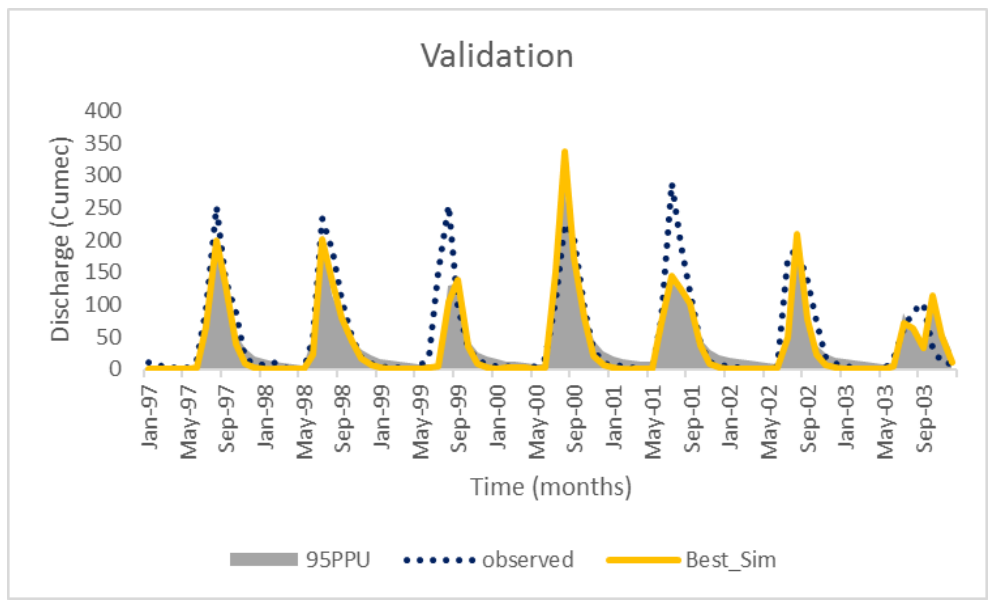

Table.1 The sources of input data

Data
Soil

Land use

Rainfall and

Temperature

Discharge

DEM

\section{Source}

The soil map obtained from the Harmonized World Soil Database (HWSD) developed by the Food and Agriculture Organization of the United Nations (FAO-UN)

The land use map collected from National Remote Sensing Centre (NRSC). (https://www.nrsc.gov.in/).

Daily rainfall and temperature (1980-2013) gridded $\left(1^{\circ} * 1^{\circ}\right)$ data were collected from the India Meteorological Department (IMD), Pune.

Daily discharge data (1980-2013) was collected from the Water Resources Information System of India (India-WRIS)

The Digital Elevation Model (DEM) was collected from Shuttle Radar Topography Mission (SRTM90) of USGS (http://srtm.csi.cgiar.org) 
Table.2 Sensitivity of SWAT parameters

\begin{tabular}{|c|c|c|c|c|c|}
\hline & & & \multicolumn{2}{|c|}{ Parameter range } & \\
\hline SI. No. & Parameter & Description & Minimum & Maximum & Fitted Value \\
\hline 1 & r_CN2.mgt & $\begin{array}{l}\text { Soil Conservation Service curve } \\
\text { number for AMC II }\end{array}$ & -0.05 & 0.05 & 0.02 \\
\hline 2 & v_ALPHA_BF.gw & $\begin{array}{l}\text { Baseflow recession alpha factor } \\
\text { (days) }\end{array}$ & 0 & 1 & 0.20 \\
\hline 3 & a_GW_DELAY.gw & Groundwater delay (day) & 0 & 500 & 250 \\
\hline 4 & a_GWQMN.gw & $\begin{array}{l}\text { Threshold water depth in the } \\
\text { shallow aquifer required for } \\
\text { return flow to occur ( } \mathrm{mm})\end{array}$ & 0 & 5000 & 2500 \\
\hline 5 & v_ESCO.hru & $\begin{array}{l}\text { Soil evaporation compensation } \\
\text { factor }\end{array}$ & 0.01 & 0.3 & 0.1 \\
\hline 6 & r_SOL_AWC().sol & $\begin{array}{l}\text { Available water capacity } \\
(\mathrm{mm} / \mathrm{mm})\end{array}$ & 0 & 500 & 20 \\
\hline 7 & v_GW_REVAP.gw & Groundwater revap coefficient & -0.25 & 0.25 & 0.19 \\
\hline 8 & v__REVAPMN.gw & $\begin{array}{l}\text { Threshold depth of water in } \\
\text { shallow aquifer for revap to occur }\end{array}$ & -0.25 & 0.25 & 0.15 \\
\hline 9 & v__SURLAG.bsn & $\begin{array}{l}\text { Surface runoff lag coefficient } \\
\text { (day) }\end{array}$ & 0.5 & 5 & 3 \\
\hline
\end{tabular}

Table.3 Model performance during calibration and validation

\begin{tabular}{|l|l|l|l|} 
Catchment & Statistical Indicators & $\begin{array}{l}\text { Monthly calibrated } \\
\text { value(1988- 1996) }\end{array}$ & $\begin{array}{l}\text { Monthly validated } \\
\text { value(1997-2003) }\end{array}$ \\
\hline Altuma & NSE & 0.74 & 0.67 \\
& $R^{2}$ & 0.78 & 0.69
\end{tabular}

For better performance of model, the value of $\mathrm{R}^{2}$ should be greater than 0.5 (Van Liew et al., 2003) and the value of NSE should be greater than 0.75 for good simulation and the NSE value greater than 0.36 gives satisfactory performance of the model (Nash and Sutcliffe, 1970). In this study, the performance indices NSE and $\mathrm{R}^{2}$ values were found to be 0.74 and 0.78 during calibration and 0.67 and 0.69 during validation periods, respectively (Table 3). Hence, the results of NSE and $\mathrm{R}^{2}$ indicate that the model performance is good.

The performance of the SWAT model was evaluated in this study for simulating streamflow in the Altuma catchment based on statistical indicators. The model was calibrated and validated based on monthly time scale using SUFI-2 algorithm. The sensitivity of model parameter was evaluated by global sensitivity analysis. The curve number (CN2) and base flow alpha factor (ALPHA_BF) are the most sensitive parameters. The uncertainty in the model is expressed in ninety-five percent prediction uncertainty (95PPU). The uncertainty in the model is within permissible limits. The performance of the model evaluated by NashSutcliffe efficiency (NSE) and coefficient of determination $\left(\mathrm{R}^{2}\right)$ statistical methods. The higher value of NSE and $\mathrm{R}^{2}$ indicates, the performance of the model is good. 


\section{References}

Abbaspour, K. C., (2015). SWAT-CUP: SWAT Calibration and Uncertainty Programs-A User Manual.

Abbaspour, K. C., Yang, J., Maximov, I., Siber, R., Bogner, K., Mieleitner, J., Zobrist, J., Srinivasan, R., (2007). Modelling hydrology and water quality in the pre-alpine/alpine Thur watershed using SWAT. J Hydrol, 333:413-430.

Arnold, J. G., Srinivasan, R., Muttiah, R. S., and Williams, J. R., (1998). Large area hydrologic modeling and assessment. Part I: Model development1. J. Am. Water Resour. Assoc., 34(1): 73-89.

Dahal, V., Shakya, N. M., and Bhattarai, R., (2016). Estimating the impact of climate change on water availability in Bagmati Basin, Nepal. Environmental Processes, 3(1):1-17.

Goyal, M. K., Madramootoo, C. A., and Richards, J. F., (2014). Simulation of the Streamflow for the Rio Nuevo Watershed of Jamaica for Use in Agriculture Water Scarcity Planning. J. Irrig. Drain Eng., 141(3): 140-156.

Mishra, A., Froebrich, J., Gassman, P.W., (2007). Evaluation of the SWAT model for assessing sediment control structures in a small watershed in India. Transactions of the ASABE, 50(2): 469477.

Nash, J. E, Sutcliffe, J., (1970). River flow forecasting through conceptual models: part I-a discussion of principles. J Hydrol, 10:282-290.
Patel, D., Srivastava, P., (2013). Flood hazards mitigation analysis using remote sensing and GIS: correspondence with town planning scheme. Water Resour. Manag, 27:2353-2368.

Pinto, D., Da Silva, A.M., Beskow, S., De Mello, C. R., Coelho, G., (2013). Application of the Soil and Water Assessment Tool (SWAT) for sediment transport simulation at a headwater watershed in Minas Gerais state, Brazil. Transactions of the ASABE, 56(2): 697709.

Sun, R., Zhang, X., Sun, Y., Zheng, D., and Fraedrich, K., (2013). SWATbased streamflow estimation and its responses to climate change in the Kadongjia River watershed, southern Tibet. J. Hydrometeorol., 14(5), 1571-1586.

Van L. M. W., Arnold, J. G., Garbrecht, J. D., (2003). Hydrologic simulation on agricultural watersheds: Choosing between two models. Trans. ASAE, 46(6): 1539-1551.

Yesuf, H. M., Melesse, A. M., Zeleke, G., and Alamirew, T., (2016). Streamflow prediction uncertainty analysis and verification of SWAT model in a tropical watershed, Environ Earth Sci., 75-80.

Zhang, X., Srinivasan, R., Liew, M. V., (2010). On the use of multi- algorithm, genetically adaptive multi-objective method for multi-site calibration of the SWAT model. Hydrol Process, 24:955969.

\section{How to cite this article:}

Padhiary, J., D.M. Das, A.P. Sahu and Sahoo, B.C. 2018. Modelling Stream Flow of Altuma Catchment using SWAT. Int.J.Curr.Microbiol.App.Sci. 7(05): 2794-2799. doi: https://doi.org/10.20546/ijcmas.2018.705.325 